\title{
Article \\ The Impact of Entrepreneurship on Economic Growth within a City
}

\author{
Xiaoyan Huang * and Yuli Chen
}

Citation: Huang, X.; Chen, Y. The Impact of Entrepreneurship on Economic Growth within a City. Businesses 2021, 1, 142-150. https:/ / doi.org/10.3390/businesses1030011

Academic Editor: Lester Johnson

Received: 30 July 2021

Accepted: 10 September 2021

Published: 13 October 2021

Publisher's Note: MDPI stays neutral with regard to jurisdictional claims in published maps and institutional affiliations.

Copyright: (c) 2021 by the authors. Licensee MDPI, Basel, Switzerland. This article is an open access article distributed under the terms and conditions of the Creative Commons Attribution (CC BY) license (https:// creativecommons.org/licenses/by/ $4.0 /)$.
Faculty of Business, City University of Macau, Macao 999078, China; b18091101461@cityu.mo

* Correspondence: ellehuang@cityu.mo

Abstract: Entrepreneurship usually takes place in innovative systems, mostly in cities. Cities, with unique features, may alter the impact of entrepreneurship. This paper employs multiple regression models to assess the impact of entrepreneurship on economic growth, considering the moderation effect of the city context. We use Gross Domestic Product (GDP) as the dependent variable and government spending, labor, fixed and financial capital and entrepreneurship as the independent variables. The data are from the 2003-2017 yearbooks of Zhaoqing, Shantou and Meizhou (three cities with distinct cultural and geographic features in Guangdong, China). We conclude that (1) the three cities' GDPs highly rely on traditional factors of production (i.e., government spending, labor and fixed and financial capital) rather than entrepreneurship and (2) the city context of Meizhou is relatively unsupportive of its entrepreneurship contributing to the GDP, in comparison with that of Zhaoqing and Shantou. This study adds to the literature by empirically assessing and comparing three cities' entrepreneurship development in China; it also informs scholars and practitioners of the moderation effect of the city context.

Keywords: economic growth; local development; entrepreneurship; entrepreneurial ecosystem; moderation effect

\section{Introduction}

As West [1] put it: "If we therefore insist on continuous open-ended growth, not only does the pace of life inevitably quicken, but we must innovate at a faster and faster rate" (p. 31). To sustain the economy, we need continuous innovation and entrepreneurship, which usually takes place in cities. With tangible and intangible features, cities affect entrepreneurship efforts and outcomes in various ways. For example, a city's culture, as a place-specific feature, may bolster the city's entrepreneurial activities over a long period of time [2-6].

Studies on entrepreneurship and growth cover a wide range of fields (e.g., macroeconomy, microeconomy, economic welfare) at different geographic levels and across different areas [7,8]. At the country level, Van Stel et al. [9] estimates the macro-economic effects of entrepreneurship across 26 OECD countries and finds that the equilibrium rate of solo self-employment is independent of the levels of economic development and (both positive and negative) deviations from the equilibrium rate would diminish growth. Conversely, Nikolaev et al. [7] reveal that the levels of economic freedom are the strongest indicator for entrepreneurship based on a world sample of 73 countries. At the regional level, most studies focus on the role of entrepreneurial ecosystems [10-13] and the role of their components such as culture, geography and institutions [14-16].

This study assesses the impact of entrepreneurship on economic growth in three cities in China, considering the moderation effect of the city context (e.g., culture, geography, institution). The paper is organized as follows. Section 2 summarizes relevant literature on the relationship between entrepreneurship and economic growth as well as the measurement of entrepreneurship. Section 3 introduces the data source (three cities in Guangdong, China) and research method (multiple regression). Section 4 presents the results of multiple 
regression models. Section 5 discusses the findings, reflects on the method and links to the literature. Section 6 concludes the research.

\section{Literature Review}

In general, entrepreneurship promotes economic growth for its innovative nature [17-23]. As the neoclassical theories suggest, growth is mainly determined by fixed capital, financial capital, labor, technology and entrepreneurship [24,25]. Entrepreneurs promote growth by managing resources in new ways [26]. This innovative type of growth is more organic than the type of growth relying on physical capital. However, entrepreneurship may also curb growth $[5,8,27]$. It is understandable that as a popular term, it may attract more money and people than it truly deserves, resulting in an unreasonable allocation of resources.

The context (or ecosystem) may affect the relationship between entrepreneurship and economic growth. Theoretical and empirical studies have explored the components, conditions and processes of ecosystems conducive to or inhibitive of entrepreneurship [5,28-30]. For example, Isenberg [31] formulates six critical components of an entrepreneurial ecosystem (i.e., policy, finance, culture, supports, human capital and markets). The World Economic Forum [30] finds that access to markets and high-quality human and financial capital are favorable conditions for successful entrepreneurship. Recently, Stam and van de Ven [29] laid out the procedural structure of a theoretical ecosystem with three layers, that is, institutional arrangements, resource endowments and output (i.e., productive entrepreneurship), which suggests that entrepreneurship can be viewed as an emergent phenomenon in complex systems. Meanwhile, the ecosystem can also be considered as a context that moderates the relationship between entrepreneurship and growth $[10,32]$. In sum, the ecosystem may derive entrepreneurship or be the platform of the relationship between entrepreneurship and economic outcome.

To measure entrepreneurship, researchers mainly take five perspectives: self-employment, new firm formation, early-stage entrepreneurship, necessity entrepreneurship and opportunity entrepreneurship [33,34]. The first two (i.e., self-employment, new firm formation) apply to almost any entrepreneurship research, while the other three have special focuses. Entrepreneurship essentially means to create something new; self-employment can be considered as a sole proprietorship that encourages innovation. The new firm formation is an extended version of self-employment; it is a key metric because new ways of production are usually carried out by a firm. Early-stage entrepreneurship depicts the critical period of the life and death of entrepreneurial attempts; it is the main driver of growth, knowledge diffusion and new job creation $[7,35,36]$. Necessity and opportunity entrepreneurship discusses the causes and consequences for different types of entrepreneurship. Necessity entrepreneurship suggests that the entrepreneur has no better alternative career choice; opportunity entrepreneurship suggests that the entrepreneur aims to take advantage of a business opportunity. Additionally, entrepreneurship can be measured indirectly through innovation [35,37] or competition [38-40].

\section{Data and Methods}

\subsection{Data}

We use data from the 2003-2017 yearbooks of three cities, Zhaoqing (ZQ), Shantou (ST) and Meizhou (MZ) in Guangdong, China [41-43]. These cities have similar population sizes but distinct cultures and geographic features. Zhaoqing is the birthplace of Guangfu culture (e.g., embracing, metropolitan) and the Cantonese language, which is the official dialect in Guangdong province. The city has an area of about 15,000 square kilometers and a population of about 4.1 million, as of 2019; it is also the closest to the provincial capital, Guangzhou (about 110 kilometers away). Conversely, ST and MZ are located at about equal distance from the provincial capital (about 420 kilometers away). ST represents the Chaoshan culture (e.g., hardworking, business-oriented). It is a coastal city with a population size of about 4.2 million, as of 2019; its area size is about 2199 square kilometers, much smaller than the other two cities. MZ represents the Kejia culture (e.g., traditional, 
self-sufficient). It is located in a remote mountainous area at the provincial border, with an area of about 15,865 square kilometers and a population of about 5.5 million, as of 2019 .

\subsection{Methods}

According to neoclassical economic theories [24,25], growth is mainly determined by fixed capital, financial capital, labor, technology and entrepreneurship. We assume that the technology levels are unchanged in the study areas during the study period. We additionally take government spending into consideration since growth is measured by Gross Domestic Product (GDP). In other words, growth (GDP) is a function of fixed capital, financial capital, labor and government spending.

We use two models to assess the relationship between entrepreneurship and growth. Model 1 captures the relationship for individual cities (i.e., ZQ, ST, MZ), shown in Equation (1); Model 2 captures the overall characteristics of the relationship by combining the three cities (i.e., ZQ, ST, MZ), shown in Equation (2). By introducing city dummies, Model 2 allows comparisons among the individual cities. In Model 2, we consider the moderation (rather than mediation) effect of the city context on the impact of entrepreneurship on growth, shown in Figure 1. To operationalize the moderation effect, we add interaction terms between city dummies and entrepreneurship indicators to the equation. Note that Model 2 has three dummies for three cities - this is just for expression convenience. When two of the dummies are in operation, the last one will be omitted.

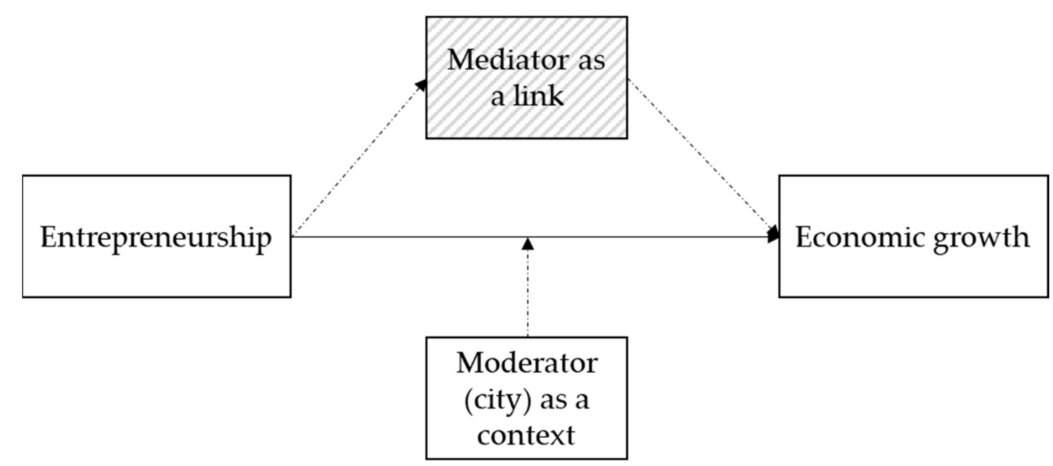

Figure 1. Research framework.

Model 1:

$$
Y=\alpha+\beta_{1} X_{1}+\beta_{2} X_{2}+\beta_{3} X_{3}+\beta_{4} X_{4}+\beta_{5} X_{5}+\beta_{6} X_{6}+\beta_{7} X_{7}+\beta_{8} X_{8}+\beta_{9} X_{9}+\varepsilon
$$

Model 2:

$$
Y=\alpha+\beta_{1} X_{1}+\beta_{2} X_{2}+\beta_{3} X_{3}+\beta_{4} X_{4}+\beta_{5} X_{5}+\beta_{6} X_{6}+\beta_{7} X_{7}+\beta_{8} X_{8}+\beta_{9} X_{9}+\beta_{10} D_{1}+\beta_{11} D_{2}+\beta_{12} D_{3}+\sum_{i=1}^{12} \sum_{j=1}^{3} \sum_{k=1}^{4} \varphi_{i} D_{j} X_{k}+\varepsilon
$$

where,

$\mathrm{Y}-\mathrm{GDP}$

$\mathrm{X}_{\mathrm{k}}$-Potential independent variables, $\mathrm{k}=1,2 \ldots 9$; see Table 1 for denotations.

$\mathrm{D}_{\mathrm{j}}$ - City dummies, $\mathrm{j}=1,2,3$; see Table 1 for denotations.

$\alpha, \beta_{\mathrm{i}}$-Coefficients to be estimated, $\mathrm{i}=1,2,3,4,5,6,7,8,9,10,11,12$.

E-Error term

As shown in Table 1, we use nine potential variables to represent each of the four components suggested by neoclassical economic theories. Variables $\mathrm{X}_{5}, \mathrm{X}_{8}$ and $\mathrm{X}_{9}$ represent fixed and financial capitals; $X_{6}$ represents government spending; $X_{7}$ represents labor; and $X_{1}, X_{2}, X_{3}$ and $X_{4}$ represent entrepreneurship. $X_{1}$ and $X_{2}$, two private enterprise metrics, can represent entrepreneurship because private enterprises own much autonomy compared to China's state-owned enterprises. The number of enterprises $\left(X_{1}\right)$ also imply competition 
(which affects innovation). $X_{2}$ is a substitute for self-employment rate and $X_{3}$ is a substitute for new firm formation rate, due to the lack of direct measurement data. $X_{4}$ measures how much a city emphasizes $R \& D$, a key activity toward innovation.

Table 1. Description of model variables.

\begin{tabular}{|c|c|c|c|}
\hline Variable Type & Short Form & Denotation & Description \\
\hline Dependent variable & GDP & $\mathrm{Y}$ & GDP of a city \\
\hline \multirow{4}{*}{$\begin{array}{l}\text { Independent variable } \\
\text { (representing } \\
\text { entrepreneurship) }\end{array}$} & Private enterprises & $X_{1}$ & Number of private enterprises \\
\hline & $\begin{array}{l}\text { Private employment } \\
\text { ratio }\end{array}$ & $X_{2}$ & $\begin{array}{c}\text { Employment ratio of private enterprise } \\
\text { (private enterprise employment divided by } \\
\text { total employment) }\end{array}$ \\
\hline & $\begin{array}{l}\text { Increased enterprise } \\
\text { ratio }\end{array}$ & $x_{3}$ & $\begin{array}{c}\text { Net Increased enterprise ratios per employee } \\
\text { (number of net Increased enterprise ratios } \\
\text { divided by total employment) }\end{array}$ \\
\hline & Industrial R\&D ratio & $\mathrm{X}_{4}$ & $\begin{array}{l}\text { Industrial R\&D ratio (industrial R\&D } \\
\text { expenditure divided by industrial output) }\end{array}$ \\
\hline \multirow{5}{*}{$\begin{array}{l}\text { Controlling variables } \\
\text { (representing the main factors } \\
\text { of production) }\end{array}$} & Fixed capital & $X_{5}$ & Fixed asset investment \\
\hline & Government spending & $X_{6}$ & Government spending \\
\hline & Labor & $X_{7}$ & Total employment in the city \\
\hline & Deposits & $\mathrm{X}_{8}$ & $\begin{array}{l}\text { Local and foreign currency deposits by } \\
\text { Chinese and foreign financial institutions }\end{array}$ \\
\hline & Loans & $X_{9}$ & $\begin{array}{l}\text { Local and foreign currency loans by Chinese } \\
\text { and foreign financial institutions }\end{array}$ \\
\hline \multirow{3}{*}{ City dummies } & ZQ & $\mathrm{D}_{1}$ & $\begin{array}{l}\text { Zhaoqing city (with embracing and } \\
\text { metropolitan features) }\end{array}$ \\
\hline & ST & $\mathrm{D}_{2}$ & $\begin{array}{l}\text { Shantou city (with hardworking and } \\
\text { business-oriented features) }\end{array}$ \\
\hline & $\mathrm{MZ}$ & $\mathrm{D}_{3}$ & $\begin{array}{l}\text { Meizhou city (with traditional and } \\
\text { self-sufficient features) }\end{array}$ \\
\hline
\end{tabular}

\section{Results}

As the descriptive statistics show, each city has a consecutive 15 years of data, ZQ's and ST's GDPs are over two hundred billion Yuan, twice that of MZ (Table 2). However, MZ's number of private enterprises (7014) is more than that of ZQ (6132) and less than that of ST (10971), which is not consistent with the ranks of the cities' GDP. This suggests that private enterprises in $\mathrm{MZ}$ might not be effective in adding value to the economy. Additionally, the industrial $\mathrm{R} \& \mathrm{D}$ ratio in $\mathrm{MZ}$ is quite low, $40 \%$ of that in $\mathrm{ZQ}$ and $0.3 \%$ of that in ST; this aligns with the traditional and self-sufficient culture in MZ.

As the correlation results show, each city's GDP is highly correlated with the traditional factors; the coefficients are generally over 0.8. Almost any of the traditional factors of production can be the sole predictor of GDP; the factors may also replace one another without compromising the fitness level of the model. Additionally, the city dummies ZQ and ST have similar correlation patterns but the city dummy MZ has negative correlations with all other variables, indicating that MZ's growth generally is less desirable than the other two cities. 
Table 2. Descriptive statistics.

\begin{tabular}{|c|c|c|c|c|c|c|c|c|c|c|c|}
\hline & $\begin{array}{l}\text { Short } \\
\text { Form }\end{array}$ & $\begin{array}{c}\text { GDP } \\
(100 \\
\text { Million } \\
\text { Yuan) }\end{array}$ & $\begin{array}{l}\text { Private } \\
\text { Enter- } \\
\text { prises } \\
\text { Ratio }\end{array}$ & $\begin{array}{l}\text { Private } \\
\text { Employ- } \\
\text { ment } \\
\text { Ratio }\end{array}$ & $\begin{array}{c}\text { Increased } \\
\text { Enterprise } \\
\text { Ratio }\end{array}$ & $\begin{array}{c}\text { Industrial } \\
\text { R\&D } \\
\text { Ratio }\end{array}$ & $\begin{array}{l}\text { Fixed } \\
\text { Capital }\end{array}$ & $\begin{array}{l}\text { Government } \\
\text { Spending }\end{array}$ & Labor & Deposits & Loans \\
\hline & Variable & Y & $X_{1}$ & $X_{2}$ & $X_{3}$ & $X_{4}$ & $X_{5}$ & $X_{6}$ & $X_{7}$ & $\mathrm{X}_{8}$ & $X_{9}$ \\
\hline & Obs. & 15 & 15 & 15 & 15 & 15 & 15 & 15 & 15 & 15 & 15 \\
\hline \multirow{3}{*}{ Mean } & ZQ & 1170.590 & 6132.333 & 0.134 & 2.920 & 0.005 & 683.344 & 139.639 & 213.970 & 1143.688 & 724.963 \\
\hline & ST & 1246.993 & $10,971.000$ & 3.895 & 0.002 & 6.776 & 626.404 & 147.911 & 215.618 & 1907.485 & 769.994 \\
\hline & $\mathrm{MZ}$ & 623.745 & 7014.867 & 0.118 & 4.650 & 0.002 & 276.198 & 167.357 & 211.738 & 958.773 & 430.419 \\
\hline \multirow{3}{*}{$\begin{array}{l}\text { Std. } \\
\text { Dev. }\end{array}$} & ZQ & 661.845 & 2858.352 & 0.061 & 5.911 & 0.003 & 488.110 & 89.737 & 7.371 & 616.987 & 446.660 \\
\hline & ST & 577.674 & 4097.959 & 5.907 & 0.001 & 5.121 & 588.795 & 96.778 & 29.395 & 854.117 & 368.520 \\
\hline & $\mathrm{MZ}$ & 279.404 & 4260.679 & 0.044 & 6.432 & 0.001 & 227.622 & 130.248 & 2.422 & 542.376 & 258.963 \\
\hline \multirow{3}{*}{ Min } & ZQ & 328.301 & 1650.000 & 0.064 & -16.234 & 0.002 & 114.660 & 31.900 & 193.860 & 392.660 & 232.129 \\
\hline & ST & 498.425 & 5724.000 & -12.960 & 0.001 & 0.554 & 119.240 & 44.540 & 163.490 & 802.430 & 421.364 \\
\hline & $\mathrm{MZ}$ & 238.382 & 2476.000 & 0.041 & -10.749 & 0.000 & 78.790 & 38.540 & 208.068 & 360.070 & 204.785 \\
\hline \multirow{3}{*}{ Max } & ZQ & 2110.005 & $10,565.000$ & 0.280 & 12.902 & 0.016 & 1497.550 & 271.154 & 221.306 & 2259.760 & 1501.964 \\
\hline & ST & 2350.975 & $18,639.000$ & 16.427 & 0.005 & 15.427 & 2006.400 & 331.633 & 239.757 & 3341.599 & 1551.715 \\
\hline & MZ & 1075.425 & $16,901.000$ & 0.177 & 15.985 & 0.004 & 806.770 & 395.175 & 216.547 & 2014.785 & 984.543 \\
\hline
\end{tabular}

Table 3 shows the estimation results of Model 1 and Model 2. Model 1 estimates the relationship for three cities individually. For $\mathrm{ZQ}, \mathrm{X}_{6}$ is the only explanatory variable. Given $\mathrm{X}_{6}$ 's correlation coefficient (0.996) with the GDP, the model's fitness (adjusted R-squared) remains over $99 \%$. For ST, fixed and financial capital are the best predictors. MZ is the only city that has an entrepreneurship indicator, $X_{2}$, among the best predictors. Interestingly, MZ's $X_{7}$ negatively affects GDP. Considering MZ as a remote city with traditional culture, this relationship can be explained by the city's transformation from low to high productivity, which reduces labor but increases GDP.

Table 3. Regression results of Model 1 and Model 2.

\begin{tabular}{|c|c|c|c|c|}
\hline \multirow{3}{*}{ Variable } & \multicolumn{4}{|c|}{ Dependent Variable: GDP } \\
\hline & \multicolumn{3}{|c|}{ Model 1} & \multirow{2}{*}{$\frac{\text { Model } 2}{\mathrm{ZQ}+\mathrm{ST}+\mathrm{MZ}}$} \\
\hline & ZQ & ST & MZ & \\
\hline Constant & $\begin{array}{l}145.34 \\
(31.90)\end{array}$ & $\begin{array}{l}108.71 \\
(41.79)\end{array}$ & $\begin{array}{l}1808.16 \\
(624.68)\end{array}$ & $\begin{array}{l}-747.03 \\
(194.32)\end{array}$ \\
\hline \multicolumn{5}{|l|}{$\begin{array}{l}\text { Private enterprises } \\
\qquad\left(\mathrm{X}_{1}\right)\end{array}$} \\
\hline $\begin{array}{l}\text { Private employment ratio } \\
\qquad\left(\mathrm{X}_{2}\right)\end{array}$ & & & $\begin{array}{c}2641.86^{* * *} \\
(359.43)\end{array}$ & \\
\hline \multicolumn{5}{|l|}{$\begin{array}{l}\text { Increased enterprise ratio } \\
\qquad\left(X_{3}\right)\end{array}$} \\
\hline \multicolumn{5}{|l|}{$\begin{array}{l}\text { Industrial } \mathrm{R} \& \mathrm{D} \text { ratio } \\
\qquad\left(\mathrm{X}_{4}\right)\end{array}$} \\
\hline $\begin{array}{c}\text { Fixed capital } \\
\left(\mathrm{X}_{5}\right)\end{array}$ & & $\begin{array}{c}0.24^{* * *} \\
(0.05)\end{array}$ & & \\
\hline $\begin{array}{l}\text { Government spending } \\
\left(\mathrm{X}_{6}\right)\end{array}$ & $\begin{array}{l}7.34^{* * *} \\
(0.19)\end{array}$ & & & \\
\hline $\begin{array}{l}\text { Labor } \\
\left(X_{7}\right)\end{array}$ & & & $\begin{array}{l}-8.56^{* *} \\
(2.98)\end{array}$ & $\begin{array}{l}4.39^{* * *} \\
(0.97)\end{array}$ \\
\hline
\end{tabular}


Table 3. Cont

\begin{tabular}{|c|c|c|c|c|}
\hline \multirow{3}{*}{ Variable } & \multicolumn{4}{|c|}{ Dependent Variable: GDP } \\
\hline & \multicolumn{3}{|c|}{ Model 1} & \multirow{2}{*}{$\begin{array}{c}\text { Model } 2 \\
\mathrm{ZQ}+\mathrm{ST}+\mathrm{MZ}\end{array}$} \\
\hline & ZQ & ST & MZ & \\
\hline $\begin{array}{l}\text { Deposits } \\
\left(\mathrm{X}_{8}\right)\end{array}$ & & $\begin{array}{c}0.52^{* * *} \\
(0.04)\end{array}$ & $\begin{array}{c}0.33^{* * *} \\
(0.03)\end{array}$ & \\
\hline $\begin{array}{l}\text { Loans } \\
\left(X_{9}\right)\end{array}$ & & & & $\begin{array}{c}1.35^{* * *} \\
(0.04)\end{array}$ \\
\hline \multicolumn{5}{|l|}{$\begin{array}{c}\mathrm{ZQ} \\
\left(\mathrm{D}_{1}\right)\end{array}$} \\
\hline \multicolumn{5}{|l|}{$\begin{array}{l}\mathrm{ST} \\
\left(\mathrm{D}_{2}\right)\end{array}$} \\
\hline \multicolumn{5}{|l|}{$\begin{array}{l}\mathrm{MZ} \\
\left(\mathrm{D}_{3}\right)\end{array}$} \\
\hline $\begin{array}{c}\text { Interaction between } \\
\text { entrepreneurship }\left(X_{1}, X_{2}, X_{3}, X_{4}\right) \\
\text { and city dummy } \\
\left(D_{1}, D_{2}, D_{3}\right)(X * D)\end{array}$ & & & & $\begin{array}{l}-0.02 * * * \\
(0.00) \\
X_{1}^{*} D_{3}\end{array}$ \\
\hline Adj. $\mathrm{R}^{2}$ & 0.99 & 0.99 & 0.99 & 0.97 \\
\hline Obs. & 15 & 15 & 15 & 45 \\
\hline
\end{tabular}

Model 2 estimates the relationship for three cities combined. The result shows that (1) overall, a city's labor (employment size) and financial loans positively contribute to its GDP; and (2) the number of private enterprises in MZ contributes slightly less to its GDP than those in $\mathrm{ZQ}$ and ST, indicated by the interaction term between $\mathrm{X}_{1}$ (number of private enterprises) and MZ (city dummy). In other words, the moderation effect of the city context in MZ hampers the impact of entrepreneurship on growth.

\section{Discussion}

This research finds that traditional factors of production are still the main contributors to each city's GDP and that the number of private enterprises in MZ contributes slightly less to its GDP than those in ZQ and ST. The first result is expected. Since they are the third-tier cities in China, it is understandable that their regional entrepreneurship has not played a key role in economic activity. As for the second result, it is also expected, since $\mathrm{MZ}$ is remotely located in the inland mountainous area, unlike Zhaoqin and Shantou. After all, access to markets is one of the crucial factors for successful entrepreneurship [5,30,44]

The research design of this study is similar to that of Belitski and Desai [10], which assessed the relationship between creativity and urban economic development considering the moderation effect of the melting pot environment (as one of its hypotheses, i.e., $\mathrm{H} 1 \mathrm{~b}$ ). In other words, the city context or melting pot environment (both are synonyms for the entrepreneurial ecosystem) plays a moderation role in the relationship between factors of production (including entrepreneurship) and economic outcome. However, the entrepreneurial ecosystem may also derive productive entrepreneurship directly [5]. Therefore, the entrepreneurial ecosystem may play two roles at the same time, i.e., generating entrepreneurship and moderating the relationship between entrepreneurship and the economic outcome.

When it comes to the selection of independent variables, this study relies on the traditional factors of production and a few entrepreneurship indicators. This enables a clear comparison between the roles of the traditional factors and entrepreneurship. As it turns out, the entrepreneurship indicators are not significant contributors to the GDP. This is not surprising, as we use linear regression models to assess the relationship. As Fritsch 
and Fritsch [21] points out, among the two main methods in the literature, while production functions could not render a causal relationship, linear regressions (usually with lags) may underestimate the impact of entrepreneurship because growth may be attributed to labor and capital rather than entrepreneurship (the way the two are organized). Note that we also have tried regression models with 1-year lags; the results are the same as reported in this paper without the lags.

The limitation of this research lies in the selection and measurement of the variables. Firstly, it does not include variables representing the role of entrepreneurs and their networks (e.g., support systems and mentors, education and training, major universities), as indicated in the literature $[30,44]$. Instead, this research generalizes the ecosystem as a dummy variable. Additionally, the measurement of the variables is coarse due to the lack of data. The scope and accuracy of data are relatively underdeveloped in the study area.

\section{Conclusions}

This research explores the relationship between regional entrepreneurship and economic growth, considering the moderation effect of the city context. We estimate the relationship for three cities separately (Model 1) and combined (Model 2). On the one hand, the regression results for individual cities reveal that traditional factors of production are still the main contributors to each city's GDP. On the other hand, the result for the combined three-city sample shows the overall and comparative characteristics of the relationship. Overall, the labor and financial capitals are the main contributors to the GDP. Comparatively, the negative coefficient of the interaction term (between the number of private enterprises and $M Z$ ) suggests that the number of private enterprises in $M Z$ contributes slightly less to its GDP than those in ZQ and ST.

We conclude that (1) the three cities' GDPs highly rely on traditional factors of production (i.e., government spending, labor and fixed and financial capital) rather than entrepreneurship and (2) the city context of Meizhou is relatively unsupportive of its entrepreneurship contributing to the GDP, compared with that of Zhaoqing and Shantou. To advance this research, we may look into the people, networks and institutions within an ecosystem especially the role of entrepreneurs [5], as well as their impact on the economy. The immediate next step is to explore the two roles of an entrepreneurial ecosystem, that is, generating entrepreneurship and moderating the relationship between entrepreneurship and the economic outcome.

Author Contributions: X.H. conceived the idea, analyzed the data and wrote the paper; Y.C. helped define the variables and collected the data. Both authors have read and agreed to the published version of the manuscript.

Funding: This research was funded by MACAO FOUNDATION, grant number MF2014.

Institutional Review Board Statement: Not applicable.

Informed Consent Statement: Not applicable.

Data Availability Statement: The data that support the findings of this study are openly available in Statistical Yearbooks at https: / /www.shantou.gov.cn/tjj/tjsj/tjnj/index.html; https:/ / www. zhaoqing.gov.cn/xxgk/tjxx/tjnj/; https:/www.meizhou.gov.cn/zwgk/sjfb/tjnj/.

Conflicts of Interest: The authors declare no conflict of interest. The funders had no role in the design of the study; in the collection, analyses, or interpretation of data; in the writing of the manuscript, or in the decision to publish the results.

\section{References}

1. West, G.B. Scale: The Universal Laws of Growth, Innovation, Sustainability, and the Pace of Life in Organisms, Cities, Economies, and Companies; Penguin: New York, NY, USA, 2017.

2. Aidis, R.; Estrin, S.; Mickiewicz, T. Institutions and entrepreneurship development in Russia: A comparative perspective. J. Bus. Ventur. 2008, 23, 656-672. [CrossRef] 
3. Fritsch, M.; Mueller, P. The effect of new business formation on regional development over time: The case of Germany. Small Bus. Econ. 2008, 30, 15-29. [CrossRef]

4. $\quad$ Fritsch, M.; Wyrwich, M. The Effect of Regional Entrepreneurship Culture on Economic Development: Evidence for Germany; (No. 2014-014); Jena Economic Research Papers; Friedrich Schiller University Jena and Max Planck Institute of Economics: Jena, Germany, 2014.

5. Stam, E. Entrepreneurial ecosystems and regional policy: A sympathetic critique. Eur. Plan. Stud. 2015, 23, 1759-1769. [CrossRef]

6. Stuetzer, M.; Audretsch, D.B.; Obschonka, M.; Gosling, S.D.; Rentfrow, P.J.; Potter, J. Entrepreneurship culture, knowledge spillovers and the growth of regions. Reg. Stud. 2018, 52, 608-618. [CrossRef]

7. Nikolaev, B.N.; Boudreaux, C.J.; Palich, L. Cross-country determinants of early-stage necessity and opportunity-motivated entrepreneurship: Accounting for model uncertainty. J. Small Bus. Manag. 2018, 56, 243-280. [CrossRef]

8. Van Stel, A.; Wennekers, S.; Scholman, G. Solo self-employed versus employer entrepreneurs: Determinants and macro-economic effects in OECD countries. Eurasian Bus. Rev. 2014, 4, 107-136. [CrossRef]

9. Van Stel, A.; Carree, M.; Thurik, R. The effect of entrepreneurial activity on national economic growth. Small Bus. Econ. 2005, 24, 311-321. [CrossRef]

10. Belitski, M.; Desai, S. Creativity, entrepreneurship and economic development: City-level evidence on creativity spillover of entrepreneurship. J. Technol. Transf. 2016, 41, 1354-1376. [CrossRef]

11. Roundy, P.T.; Fayard, D. Dynamic capabilities and entrepreneurial ecosystems: The micro-foundations of regional entrepreneurship. J. Entrep. 2019, 28, 94-120. [CrossRef]

12. Sorenson, O. Regional ecologies of entrepreneurship. J. Econ. Geogr. 2017, 17, 959-974. [CrossRef]

13. Szerb, L.; Lafuente, E.; Horváth, K.; Páger, B. The relevance of quantity and quality entrepreneurship for regional performance: The moderating role of the entrepreneurial ecosystem. Reg. Stud. 2019, 53, 1308-1320. [CrossRef]

14. Barinova, V.A.; Zemtsov, S.P.; Tsareva, Y.V. Entrepreneurship and institutions: Does the relationship exist at the regional level in Russia. Vopr. Ekon. 2018 6, 92-116. [CrossRef]

15. Ratten, V.; Ferreira, J. Entrepreneurship, innovation and sport policy: Implications for future research. Int. J. Sport Policy Politics 2017, 575-577. [CrossRef]

16. Xing, Y.; Liu, Y.; Cooper, S.C.L. Local government as institutional entrepreneur: Public-private collaborative partnerships in fostering regional entrepreneurship. Br. J. Manag. 2018, 29, 670-690. [CrossRef]

17. Sexton, D.L.; Bowman-Upton, N.B. Entrepreneurship: Creativity and Growth; Macmillan Pub Co.: New York, NY, USA, 1991.

18. King, R.G.; Levine, R. Finance, entrepreneurship and growth. J. Monet. Econ. 1993, 32, 513-542. [CrossRef]

19. Davidsson, P.; Delmar, F.; Wiklund, J. Entrepreneurship as Growth; Growth as Entrepreneurship. In Strategic Entrepreneurship: Creating a New Mindset; Edward Elgar Publishing: Cheltenham, UK, 2002; Volume 6, pp. 328-342.

20. Audretsch, D.B. Entrepreneurship, economic growth, and geography. Oxf. Rev. Econ. Policy 2018, 34, 637-651. [CrossRef]

21. Fritsch, M.; Fritsch, M. The effect of new business formation on regional development-Empirical evidence, interpretation, and avenues for further research. In Handbook of Research on Entrepreneurship and Regional Development-National and Regional Perspectives; Friedrich Schiller University: Jena, Germany, 2011; pp. 58-106.

22. Prieger, J.E.; Bampoky, C.; Blanco, L.R.; Liu, A. Economic growth and the optimal level of entrepreneurship. World Dev. 2016, 82, 95-109. [CrossRef]

23. Ferreira, J.J.; Carayannis, E.G.; Campbell, D.F.; Farinha, L.; Smith, H.L.; Bagchi-Sen, S. Geography \& entrepreneurship: Managing growth and change. J. Knowl. Econ. 2018, 9, 500-505.

24. Clark, J.B. Insurance and business profit. Q. J. Econ. 1892, 7, 40-54. [CrossRef]

25. Knight, F.H. Profit and entrepreneurial functions. J. Econ. Hist. 1942, 2, 126-132. [CrossRef]

26. Schumpeter, J.A. Change and the Entrepreneur. Essays JA Schumpeter; Harvard University Press: Cambridge, MA, USA, 1934; Volume 4, pp. 45-91.

27. Bradley, S.W.; Wiklund, J.; Shepherd, D.A. Swinging a double-edged sword: The effect of slack on entrepreneurial management and growth. J. Bus. Ventur. 2011, 26, 537-554. [CrossRef]

28. Nicotra, M.; Romano, M.; Del Giudice, M.; Schillaci, C.E. The causal relation between entrepreneurial ecosystem and productive entrepreneurship: A measurement framework. J. Technol. Transf. 2018, 43, 640-673. [CrossRef]

29. Stam, E.; Van de Ven, A. Entrepreneurial ecosystem elements. Small Bus. Econ. 2021, 56, 809-832. [CrossRef]

30. World Economic Forum. Entrepreneurial Ecosystems around the Globe and Company Growth Dynamics; World Economic Forum: Davos, Switzerland, 2013.

31. Isenberg, D.J. How to start an entrepreneurial revolution. Harv. Bus. Rev. 2010, 88, 40-50.

32. Feldman, M.P. The character of innovative places: Entrepreneurial strategy, economic development, and prosperity. Small Bus. Econ. 2014, 43, 9-20. [CrossRef]

33. Desai, S. Measuring entrepreneurship: Type, motivation, and growth. IZA World Labor 2017. [CrossRef]

34. Audretsch, D. Entrepreneurship, Innovation and Economic Growth; Edward Elgar Publishing: Cheltenham, UK, 2006.

35. Anokhin, S.; Schulze, W.S. Entrepreneurship, innovation, and corruption. J. Bus. Ventur. 2009, 24, 465-476. [CrossRef]

36. Van Praag, C.M.; Versloot, P.H. What is the value of entrepreneurship? A Rev. Recent Research Small Bus. Econ. 2007, 29, 351-382.

37. Acs, Z.J.; Audretsch, D.B. Small Firms in the 1990s. In The Economics of Small Firms; Springer: Dordrecht, The Netherlands, 1990; pp. 1-22. 
38. Aghion, P.; Dewatripont, M.; Rey, P. Competition, financial discipline and growth. Rev. Econ. Stud. 1999, 66, 825-852. [CrossRef]

39. Gilbert, R. Looking for Mr Schumpeter: Where Are We in the Competition-Innovation Debate? Innov. Policy Econ. 2006, 6, 159-215. [CrossRef]

40. Etro, F. Competition, Innovation, and Antitrust: A theory of Market Leaders and Its Policy Implications; Springer Science \& Business Media: Berlin, Germany, 2007.

41. Zhaoqing Municipal Government 2003-2019. Statistical Yearbooks 2004-2018. Available online: http://www.zhaoqing.gov.cn/ xxgk/tjxx/tjnj/ (accessed on 20 March 2020).

42. Shantou Municipal Government 2003-2019. Statistical Yearbooks 2004-2018. Available online: https://www.shantou.gov.cn/tij/ tjsj/tjnj/index.html (accessed on 20 March 2020).

43. Meizhou Municipal Government 2003-2019. Statistical Yearbooks 2004-2018. Available online: https://www.meizhou.gov.cn/ Zwgk/sjfb/tjnj/ (accessed on 20 March 2020).

44. Feld, B. Startup Communities: Building an Entrepreneurial Ecosystem in Your City; Wiley: New York, NY, USA, 2012. 